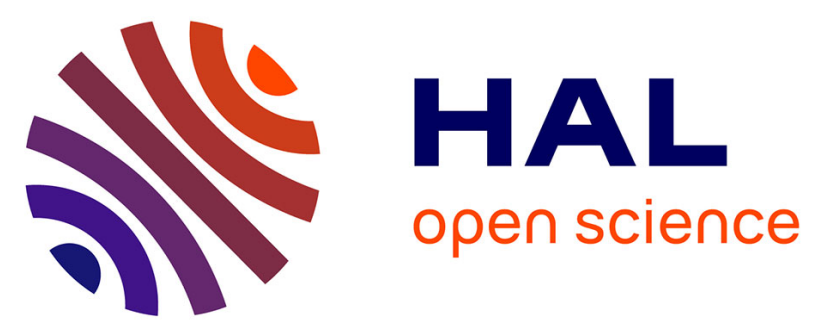

\title{
Corrosion diagnosis of reinforced concrete beams after 40 years exposure in marine environment by non destructive tools
}

Olivier Poupard, Valerie L'Hostis, Véronique Bouteiller, Bruno Capra, Sandrine Catinaud, Daniel Francois, Jean-Luc Garciaz, S. Laurens, Tang Luping, Gérard Olivier, et al.

\section{To cite this version:}

Olivier Poupard, Valerie L'Hostis, Véronique Bouteiller, Bruno Capra, Sandrine Catinaud, et al.. Corrosion diagnosis of reinforced concrete beams after 40 years exposure in marine environment by non destructive tools. Revue Européenne de Génie Civil, 2007, Benchmark des poutres de la Rance, 11 (1-2), pp.35-54. 10.1080/17747120.2007.9692921 . cea-02355765

\section{HAL Id: cea-02355765 https://hal-cea.archives-ouvertes.fr/cea-02355765}

Submitted on 2 Dec 2019

HAL is a multi-disciplinary open access archive for the deposit and dissemination of scientific research documents, whether they are published or not. The documents may come from teaching and research institutions in France or abroad, or from public or private research centers.
L'archive ouverte pluridisciplinaire HAL, est destinée au dépôt et à la diffusion de documents scientifiques de niveau recherche, publiés ou non, émanant des établissements d'enseignement et de recherche français ou étrangers, des laboratoires publics ou privés. 


\title{
Benchmark des poutres de la Rance
}

\section{Corrosion diagnosis of reinforced concrete beams after 40 years exposure in marine environment by non destructive tools}

\author{
Olivier POUPARD* — Valérie L’HOSTIS** \\ * Laboratoire Pierre Sue, CNRS/CEA Saclay, France. \\ ** Laboratoire d'Etudes du Comportement des Bétons et des Argiles, CEA Saclay, \\ France
}

With the contribution of

\section{Véronique BOUTEILLER ${ }^{\mathrm{a}}$, Bruno CAPRA $^{\mathrm{b}}$, Sandrine CATINAUD $^{c}$, Daniel FRANCOIS ${ }^{d}$, Jean Luc GARCIAZ ${ }^{e}$, Stéphane LAURENS ${ }^{f}$, Tang LUPING ${ }^{g}$, Gérard OLIVIER ${ }^{\mathrm{h}}$, Guy TACHE .}

${ }^{a}$ LCPC, Paris.

${ }^{b}$ OXAND S.A.

${ }^{c}$ CEBTP-SOLEN, Saint Rémy les Chevreuse

${ }^{d} \mathrm{EDF} / \mathrm{OPP}$.

${ }^{e}$ LERM.

${ }^{f}$ LMDC/INSA-UPS Toulouse

${ }^{g}$ SP Institute, Suède

${ }^{h}$ LREP, Melun

email adress: valerie.lhostis@cea.fr

RÉSUMÉ. Cet article décrit le programme expérimental mis en place dans le cadre du Benchmark des poutres de la Rance. Il présente le diagnostic vis-à-vis de la corrosion de poutres en béton précontraint ayant séjourné 40 ans en environnement marin. Ce papier inclut les résultats issus des techniques d'auscultation non destructive, les tests complémentaires en laboratoire et les analyses destructives. Ce projet permet de bénéficier d'une large banque de données sur l'état de corrosion des poutres après 40 années (mécanique, électrochimiques et propriétés physico-chimiques) et d'apprécier la sensibilité des techniques non destructives pour évaluer des risques de corrosion au sein de structures en béton précontraint. Ces résultats sont fournis aux équipes de modélisation afin de compléter leurs conditions de tests en vue de la validation des modèles de comportement mécanique.

ABSTRACT. This paper describes the detailed experimental program of the French national project "Benchmark des poutres de la Rance". It presents a corrosion diagnosis of 
prestressed beams after 40 years exposure in natural marine environment. It includes results from non destructive testing tools, complementary laboratory tests and destructive analyses. This project will provide a large database on the corrosion state of reinforced concrete beams after 40 years exposure in a marine environment (mechanical, electrochemical and physico-chemical properties) and will allow to study the sensitivity of NDT tools to evaluate corrosion risk within reinforced concrete structures. These results will be given to the modellers in order to complete their test conditions in the framework of the validation of mechanical models.

MOTS-CLÉS : Benchmark, Béton précontraint, Corrosion, Techniques Non Destructives, Diagnostic

KEYWORDS: Benchmark, Prestressed concrete, Corrosion, Non Destructive Techniques, Diagnosis

\section{Introduction}

In the context of the civil engineering structures, rebar corrosion is a major cause of damage and early failure of reinforced-concrete structures, and consequently it is recognized as a key issue for concrete structures ageing [1]. Initially, reinforcing steel embedded in concrete is naturally protected from corrosion by the high alkalinity of its interstitial solution [1-5]. However, this passive film can be destroyed by aggressive ions (chlorides, for instance, or carbonation) [4].

The approaches usually used for designing or rehabilitating civil engineering structures are based on the estimation of the corrosion initiation time as a function of the materials properties. However, in most cases, this initiation time is exceeded, rebar is already corroding, and it is essential to know the influence of corrosion on the mechanical behavior of concrete structures. This knowledge will contribute to determine the residual margin of safety of reinforced-concrete structures to the total failure and so enhance the safety of such structures. Previous studies have shown that the mechanical behavior models are appropriate to evaluate the actual safety of concrete structures [6-8]. Now, these developments need to be validated on existing concrete structures. Moreover, it is important to take into account the recent progress in the use of non-destructive testing methods. The development of NDT applied on materials and condition assessments of bridges has become a major subject of interest for the civil engineering community.

This paper describes the main results obtained within the "Benchmark des poutres de la Rance” project concerning the physico-chemical characterization of the 20 reinforced concrete beams exposed for 40 years in a marine environment. 


\section{Methodology and detailed workprogram}

Prestressed concrete specimens are $2.5 \mathrm{~m}$ long beams (square cross-section 0.20 $\mathrm{m} \times 0.20 \mathrm{~m}$ ). The ends of the beams are protected on $0.25 \mathrm{~m}$ by an asphalt plaster. The passive reinforcements are $\varnothing 6 \mathrm{~mm}$ wires. $\varnothing 6 \mathrm{~mm}$ stirrups are disposed all $0.25 \mathrm{~m}$. The prestressed is performed with $\varnothing 7 \mathrm{~mm}$ wires, placed under a plastic sheath of $\varnothing 12 \mathrm{~mm}$, and anchored at the ends of the beams.

Table 1 and figure 1 present the characteristics and a schematic view of the five types of beams will be studied in this project. For each type of beams, two different cement mix (300 and $400 \mathrm{~kg} / \mathrm{m}^{3}$ of concrete) and two gradings (continuous and discontinuous) exist.

Table 1 : characteristics of prestressed concrete beams

\begin{tabular}{|c|c|c|c|c|c|}
\hline Designation & 1 & 2 & 4 & 6 & 9 \\
\hline $\begin{array}{l}\text { Prestressed } \\
\text { wires }\end{array}$ & $\begin{array}{c}1 \\
\text { Center }\end{array}$ & $\begin{array}{c}2 \\
\text { Center }\end{array}$ & $\begin{array}{c}2 \\
\text { Off center }\end{array}$ & $\begin{array}{c}4 \\
\text { Off center }\end{array}$ & $\begin{array}{c}2 \\
\text { Off center }\end{array}$ \\
\hline Passive steel $\phi 6$ & 14 & 14 & 12 & 10 & 12 \\
\hline \multirow{2}{*}{ Stirrup $\phi 6$} & \multicolumn{4}{|c|}{1 stirrup each $0.25 \mathrm{~m}$} & \\
\hline & $\begin{array}{c}11.8 \\
\times 16.8\end{array}$ & $\begin{array}{c}11.8 \\
\times 16.8\end{array}$ & $\begin{array}{c}16.8 \\
\times 16.8\end{array}$ & $\begin{array}{c}16.8 \\
\times 16.8\end{array}$ & $\begin{array}{c}11.8 \\
\times 14.3\end{array}$ \\
\hline $\begin{array}{l}\text { Cover in cm } \\
\mathrm{S} \text { for side }\end{array}$ & $\begin{array}{l}2 \mathrm{~S}: 1.6 \\
2 \mathrm{~S}: 4.1\end{array}$ & $\begin{array}{l}2 \mathrm{~S}: 1.6 \\
2 \mathrm{~S}: 4.1\end{array}$ & $4 \mathrm{~S}: 1.6$ & 4 S : 1.6 & $\begin{array}{l}1 \mathrm{~S}: 1.6 \\
3 \mathrm{~S}: 4.1\end{array}$ \\
\hline
\end{tabular}


Type 1

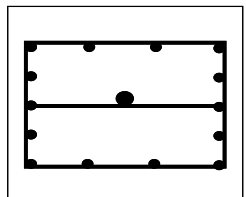

Type 2

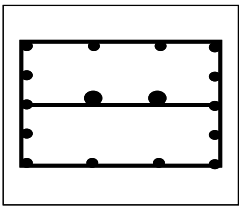

Type 4

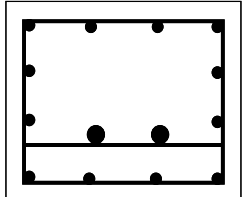

Type 6

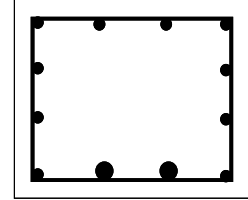

Type 9

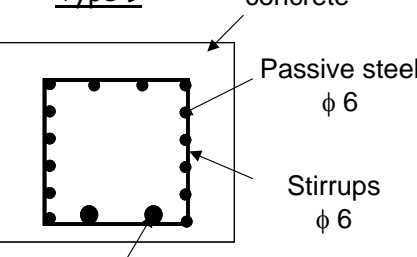

Prestressed wires $\phi 7$ under plastic film $\phi 12$

Figure 1: Schematic view of the reinforcements for the studied beams.

Table 2 summarizes the different tools used within this project to characterize corrosion state of these beams.

Table 2: Description of investigation methods and partners involved.

\begin{tabular}{|c|c|c|c|}
\hline Nature of tools & Objectives (partner & e indicated in thick) & Information \\
\hline \multirow{7}{*}{$\begin{array}{l}\text { Non-Destructive } \\
\text { Tests }\end{array}$} & \multirow[b]{2}{*}{ Visual observations } & General states of parements & Peeling, micro-craks \\
\hline & & Damage maps & $\begin{array}{l}\text { Localization of damage (crakcs, } \\
\text { « rust » areas,) ; craks openings }\end{array}$ \\
\hline & \multirow{3}{*}{$\begin{array}{l}\text { Electrochemical } \\
\text { measurements }\end{array}$} & Half-cell potential (CEBTP) & $\begin{array}{l}\text { Localization of } \\
\text { "corroded" / "uncorroded" areas }\end{array}$ \\
\hline & & $\begin{array}{l}\mathrm{R}_{\mathrm{P}} \text { measurement } \\
\text { (CEA, EDF, LCPC, LREP, } \\
\text { Oxand, LERM, SP institute) }\end{array}$ & Instantaneous corrosion rate \\
\hline & & $\begin{array}{l}\text { Resistivity } \\
\text { (LCPC, LREP, SP institute) }\end{array}$ & $\begin{array}{l}\text { Localization of heterogeneity } \\
\text { within beams }\end{array}$ \\
\hline & \multirow{2}{*}{$\begin{array}{l}\text { Electromagnetic } \\
\text { measurements }\end{array}$} & $\begin{array}{l}\text { Ferroscan, Pachometer } \\
\text { (CEBTP) }\end{array}$ & Bars detection \\
\hline & & $\begin{array}{l}\text { RADAR } \\
\text { (LMDC) }\end{array}$ & $\begin{array}{l}\text { Localization of physical } \\
\text { heterogeneity within beams }\end{array}$ \\
\hline $\begin{array}{l}\text { Semi Non- } \\
\text { Destructive Tests }\end{array}$ & $\begin{array}{l}\text { Physico-chemical } \\
\text { measurements }\end{array}$ & $\begin{array}{l}\text { Chloride profiles (LCPC) } \\
\text { Carbonation (CEBTP) }\end{array}$ & $\begin{array}{l}\text { Identification of aggressive species } \\
\text { responsible of corrosion initiation }\end{array}$ \\
\hline \multirow[b]{2}{*}{ Destructive Tests } & \multirow[b]{2}{*}{ Autopsy } & Corrosion map (CEA) & Localization of corroded areas \\
\hline & & $\begin{array}{l}\text { Mass loss, diameter loss, } \\
\text { pitting depth (CEA, EDF) }\end{array}$ & Mean corrosion rate, pitting factor \\
\hline
\end{tabular}




\subsection{Characterization from non destructive methods.}

\section{Visual inspection}

First, all the beams are visually observed. It aims to survey the beams in order to detect which type of structural damage was developed in the structures. Regarding reinforced corrosion problems, three types of visual inspection results have been performed:

- maps of cracks positions: cracks due to reinforcement corrosion are drawn taking into account the position of the visible cracks and their widths,

- corrosion maps: the locations of the rust areas on the beams are drawn,

- information on spalling, delamination and loss of concrete cover are also reported.

From the crack map, a crack factor is evaluated to compare crack damage between the studied beams. It is defined as follows (Eq. 1):

crack factor $=\sum_{i=1}^{\mathrm{N}}$ length $(\mathrm{i}) \times$ width $(\mathrm{i})$

where $\mathrm{N}$ is the number of cracks existing on the considered face of the beam.

\section{Reinforcement geometry}

The reinforcement details are obtained from magnetic measurements to control:

- concrete cover thickness,

- rebar position: transverse and longitudinal reinforcing steel bars.

\section{Electrochemical methods}

Electrochemical measurements are performed on the beams to evaluate in a nondestructive way the rebar corrosion activity. First, half-cell potentials are measured. The principle of this method is based on the measurement of the potential difference between rebars and a reference electrode. A multi-electrode device is used to collect data (three measurement lines per side and one reading per $\mathrm{cm}$ along the beam length). The reference electrode is a copper/saturated copper sulphate (CSE $=+318 \mathrm{mV} / \mathrm{NHE}$ ) electrode. Measurements are performed according to RILEM recommendations [10].

The measurement of half-cell potential is a qualitative way to mainly locate corroding areas. To characterize in a quantitative way the corrosion activity, it is essential to evaluate the steel corrosion rate. The corrosion rate, $\mathrm{V}_{\text {corr }}$, is deduced 
from the polarization resistance $\left(\mathrm{R}_{\mathrm{P}}\right)$ measurement [11]. The current density, $\mathrm{I}_{\text {corr }}$, is then obtained from Stern and Geary equation (Eq. 2) [12]:

$$
I_{\text {corr }}=\frac{B}{R_{p}}
$$

with $\mathrm{B}$ a constant parameter which varies from 13 to $52 \mathrm{mV}$ depending on the studied system. In this study, $B$ is considered as equal to $26 \mathrm{mV}$ (if $R_{P}$ and $I_{\text {corr }}$ are expressed respectively in kOhms and $\mu \mathrm{A}$ ), according to Rilem recommendations [11].

The corrosion rate can be deduced from corrosion current with the Faraday equation. If corrosion current is expressed in $\mu \mathrm{A}$, corrosion rate (in $\mu$ m.year ${ }^{-1}$ ) is given by the relation (Eq. 3) assuming uniform corrosion across the rebar surfaces:

$$
V_{\text {corr }}=11.6 \frac{I_{\text {corr }}}{A}
$$

where $\mathrm{A}$ is the steel surface area $\left(\right.$ in $\left.\mathrm{cm}^{2}\right)$.

Table 3 summarizes the different techniques used in this project to evaluate corrosion rate and to measure resistivity.

\begin{tabular}{|c|c|c|c|c|}
\hline & Institution & Technique & Device & $\begin{array}{c}\text { Counter-electrode } \\
\text { characteristic }\end{array}$ \\
\hline \multirow{5}{*}{$\begin{array}{l}\text { Corrosion } \\
\text { rate }\end{array}$} & LREP & $\begin{array}{l}\text { Galvanostatic } \\
\text { pulse }\end{array}$ & Gecor6® & $\begin{array}{l}\text { Modulated confinement } \\
\text { (guard ring with } \\
\text { control sensors) }\end{array}$ \\
\hline & $\begin{array}{l}\text { OXAND } \\
\& \text { LERM }\end{array}$ & $\begin{array}{l}\text { Galvanostatic } \\
\text { pulse }\end{array}$ & GalvaPulse ${ }^{\circledR}$ & $\begin{array}{l}\text { Confinement } \\
\text { (guard ring) }\end{array}$ \\
\hline & EDF/OPP & $\begin{array}{c}\text { Potentiostatic } \\
\text { pulse }\end{array}$ & Gamry® & No confinement \\
\hline & $\begin{array}{l}\text { CEA/SCCME } \\
\text { /LECBA }\end{array}$ & $\begin{array}{l}\text { Potentiostatic } \\
\text { pulse }\end{array}$ & Gamry® & No confinement \\
\hline & SP institute & $\begin{array}{l}\text { Galvanostatic } \\
\text { pulse }\end{array}$ & Rapicor® & $\begin{array}{c}\text { Confinement } \\
\text { (guard ring and } \\
\text { potential attenuation } \\
\text { method) }\end{array}$ \\
\hline Resistivity & $\begin{array}{c}\text { LREP } \\
\text { SP institute }\end{array}$ & & $\begin{array}{l}\text { Gecor6 }{ }^{\circledR} \\
\text { Rapicor }{ }^{\circledR}\end{array}$ & \\
\hline
\end{tabular}

Table 3: Techniques used for electrochemical measurements 


\section{Electromagnetic methods: Radar}

The general principle of radar sounding of civil engineering structures, based on the propagation of EM impulses, has been reported by many authors [13, 14]. A radar system was used in association with two high frequency ground-coupled 1.5 $\mathrm{GHz}$ antennas.

An original approach proposed by the " Diagnosis » group from the LMDC laboratory consists in using radar technology for the prediction of pathologic risks affecting concrete structures. For example, the electromagnetic properties of concrete, that govern radar wave propagation, are influenced by moisture and/or chloride content. Thus, radar measurement is sensitive to the physical condition leading to corrosion in reinforced concrete.

Previous laboratory studies [15] highlight that the energy directly radiated by the transmitter towards the receiver, named the direct wave (DW) or direct signal, can provide reliable data on the coupling material properties. In this study, a simple interpretation criterion based on the DW positive peak amplitude was tested as first approach:

- Small DW amplitude (high moisture and/or chloride content) = High corrosion risk,

- High DW amplitude (low moisture and/or chloride content) = Low corrosion risk.

Finally, it has to be mentioned that for each face of each beam, at least 5 points has been chosen to submit measurements (electrochemical and Radar).

\subsection{Characterization of the constitutive materials (reinforcing steel, prestressed cables, corrosion products and concrete)}

After the non-destructive inspection, 10 beams were used to characterize the materials properties and to estimate the aggressive species penetration (chloride profile and carbonation depth). The carbonation depths were measured by a phenolphthalein test. For this purpose, freshly broken concrete surface were sprayed with a phenolphthalein solution at various locations along the beam. Sound concrete appears red while the color of the carbonated concrete remains unchanged. This change occurs in the $\mathrm{pH}$ range 8.3-10. Powdered concrete samples were taken for determining "total" and "free" chloride contents and estimating chloride penetration profiles at different locations on the beams according AFPC-AFREM recommendations [16].

Samples were collected for each concrete type to characterize the material microstructure features (porosity, pore size) which are in strong relationship with transport properties. Mercury intrusion porosimetry tests and water absorption measurements were performed. 
The nature of corrosion products was well identified, with scanning electron microscope observations, X Ray diffractometry analysis and $\mu$-Raman method. The localized corrosion (pits) areas and depth were also measured, as well as the section loss due to generalized corrosion. Finally, the weight loss of the steel was also determined.

\section{Results}

\subsection{Chloride profiles and carbonation depth.}

Chemical tests on drilled concrete cores (for chloride profiles) and freshly splits concrete (for carbonation measurements) showed that the four types of concretes were highly contaminated by chlorides but not carbonated. For all tests, the maximum carbonation depth is about $1 \mathrm{~mm}$. Figure 2 presents the average profiles of the "free" chloride ion concentration measured at two locations along the beam. A characteristic chloride profile of a concrete structure exposed in tidal marine environment is observed with a maximum value at about $10 \mathrm{~mm}$ from the top surface and a slight decrease within bulk structure. At the reinforcing bars depth, the measured values exceed the threshold limit (0.5-1.5\% mass cement) generally pointed out in literature [16]. These results highlight that active corrosion due to chloride ingress can take place at rebars surface.

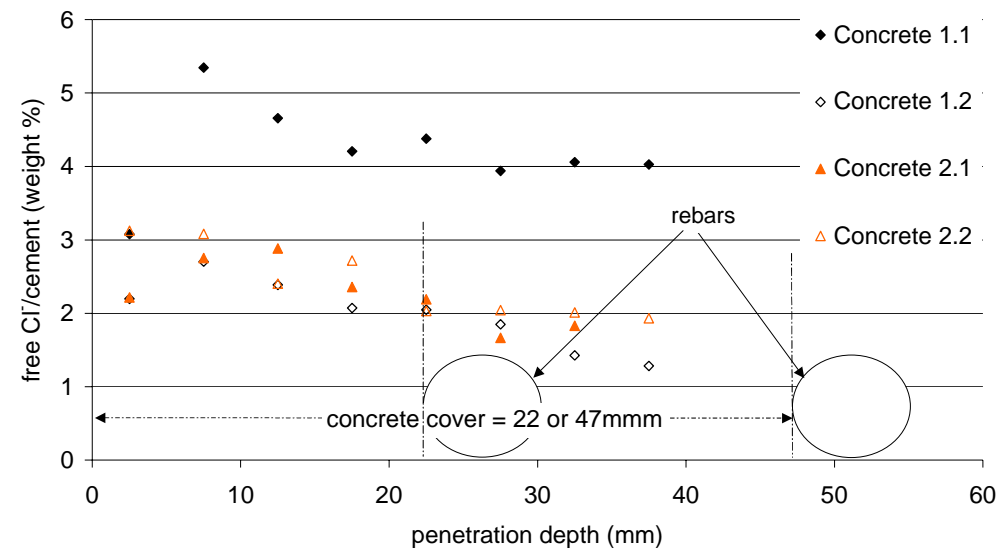

Figure 2. Water-soluble chloride concentration vs. concrete depth (the cover depth for steel is indicated on the graph). 


\subsection{Visual observations.}

A preliminary analysis of the visual observations (before and after removing concrete cover) is discussed concerning the influence of beams properties (lay-out configuration and mix concrete) on corrosion damage. Before removing concrete cover, a visual observation gives a global overview of the damage state of prestressed concrete beams after 40 years in marine environment.

Except beam 912, all beams show some longitudinal cracks due to rebar corrosion. They are often associated with some spots of rust stains. For beams type 1 and 2, the corrosion damages appear mainly on lateral sides due to a thin concrete cover (16 mm concrete cover) and little corrosion damage is observed on the upper and lower sides ( $41 \mathrm{~mm}$ concrete cover). For beams type 4, 6 and 9, cracks are mainly observed on lateral and on upper sides. When they exist, it is interesting to note that the longitudinal cracks on lateral sides are mainly located on the upper part, which corresponds to the tensioned concrete. On the contrary, the compressive area (lower part) shows few corrosion induced cracks. For some beams type 9, even if concrete cover is thick ( $41 \mathrm{~mm}$ concrete cover), important corrosion damage appears on upper part.

After removing concrete cover, the actual corrosion damage of each rebar is observed. As expected in chloride contaminated concrete, corrosion occurs in localized areas (due to pitting attack). For beams type 1 and 2, we can observe similar corrosion damage between upper and lower rebars. This can easily be explained by the fact that similar loads are applied in concrete. For beams type 4, 6 and 9, the details of corroded areas show corrosion process along the rebars located in the upper part of the beams (tensile areas). Except for some cases, rebars under compression (lower part) in these beams are weakly corroded. It is interesting to observe that the highest corrosion damage is in the upper face of type 6 beams with a thin concrete cover of $16 \mathrm{~mm}$ and prestressing cables highly eccentric. This result is consistent with the paper by Francois and Arliguie [17]. Microcracks in tensioned concrete enhance chloride and oxygen penetration in concrete and damage at steel/concrete interface.

There are large differences in corrosion behaviour depending on the concrete mixture. For a given layout configuration, concrete of type 1.2 (continuous granulometry, high cement content $400 \mathrm{~kg} . \mathrm{m}^{-3}$ ) always shows the lowest percentage of corroded areas. Conversely, beams with low cement content $\left(300 \mathrm{~kg} \cdot \mathrm{m}^{-3}\right)$ show the worst behaviour towards corrosion damage. This is in good agreement with previous studies which have shown that the water/cement ratio has a major role on the transport properties within reinforced concrete [18, 19]. The higher is this parameter, the higher is the porosity (see table 4). Therefore aggressive species (chloride, oxygen) can more easily penetrate within concrete and develop high-level corrosion at rebar surface. 
10 Revue. Volume $\mathrm{X}-\mathrm{n}^{\circ} \mathrm{x} /$ année

Table 4: Concrete mixture proportions and microstructure characterization

\begin{tabular}{|c|c|c|c|c|c|c|c|c|}
\hline \multirow{2}{*}{$\begin{array}{l}\text { Concrete } \\
\text { designation }\end{array}$} & \multirow{2}{*}{$\begin{array}{c}\text { Total } \\
\text { water } \\
\text { (l) }\end{array}$} & \multirow{2}{*}{$\begin{array}{l}\text { Cement } \\
\text { kg.m }\end{array}$} & \multicolumn{3}{|c|}{ Granulometry $\left(\mathrm{kg} / \mathrm{m}^{3}\right)$} & \multirow[t]{2}{*}{$w / c$} & \multirow{2}{*}{$\begin{array}{c}\text { Porosity } \\
\text { by MIP } \\
(\%)\end{array}$} & \multirow[t]{2}{*}{$\begin{array}{l}\text { Porosity by water } \\
\text { absorption (\%) }\end{array}$} \\
\hline & & & $\begin{array}{c}\text { Sand } \\
0 / 5\end{array}$ & $\begin{array}{c}\text { Gravel } \\
5 / 15\end{array}$ & $\begin{array}{l}\text { Gravel } \\
10 / 25\end{array}$ & & & \\
\hline 1.1 & 210 & 300 & 800 & 320 & 930 & 0.7 & 15.3 & 15.7 \\
\hline 1.2 & 210 & 400 & 550 & 290 & 930 & 0.525 & 13.1 & 13.4 \\
\hline 2.1 & 220 & 300 & 500 & I & 1350 & 0.73 & 15.7 & 16.7 \\
\hline 2.2 & 250 & 400 & 450 & 1 & 1350 & 0.625 & 14.5 & 16.4 \\
\hline
\end{tabular}

Complementary destructive methods were then applied to observe the real corrosion state of steel rebars and characterize the corrosion products and the steel/concrete interface (optical and electronical microscopy tools (XRD, SEM, EDS and $\mu$-Raman). Results have been published elsewhere [20]. The following corrosion pattern is observed: metallic substrate, corrosion product layer and concrete (Figure 3a).

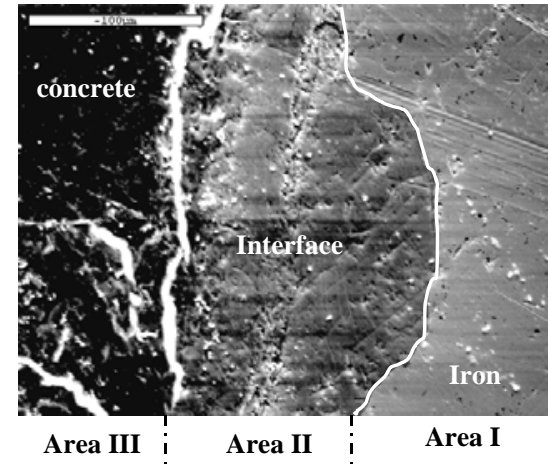

a)

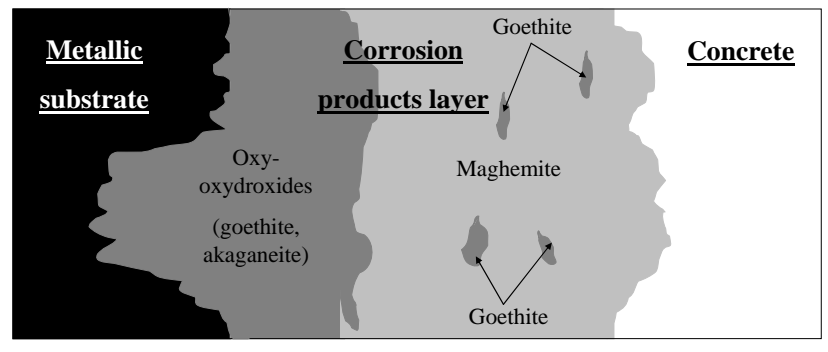

b)

Figure 3. a) Observation of the metal/concrete interface. b) Schematic description of the corrosion layer structure. 
The coupling of these techniques has allowed the identification and localisation of corrosion products. Composition and thickness of the corrosion product layer varies with the damage degree. For "low-corroded" regions (some $\mu \mathrm{m}$ in thickness), corrosion product layer is only composed of magnetite. For "high-corroded" regions, corrosion product layer (some $500 \mu \mathrm{m}$ in thickness) is mainly composed of goethite and maghemite (figure $3 \mathrm{~b}$ ). Akaganeite, which is characteristic of chloride attack, is present at the corrosion product/metallic substrate interface in some pits.

\subsection{Corrosion rates measurements - comparison between different techniques.}

Figure 4 presents the evolution of the value of corrosion rate measured with four instruments presented in table 1 for all measurements.

The first remark concerns the scales of results. The GalvaPulse ${ }^{\circledR}$ device presents the higher corrosion rate values, whereas the Gecor6® device presents lowest levels. These observations are in agreement with previous studies [21, 22]. Sometimes, differences between the two devices can be higher that 2 orders of magnitude. Measurements performed with the Gamry ${ }^{\circledR}$ potentiostat present intermediate values. Data given by EDF and CEA are consistent. This is a logical results, since the device is similar and the same procedure has been adopted (only the counter-electrode device is different).

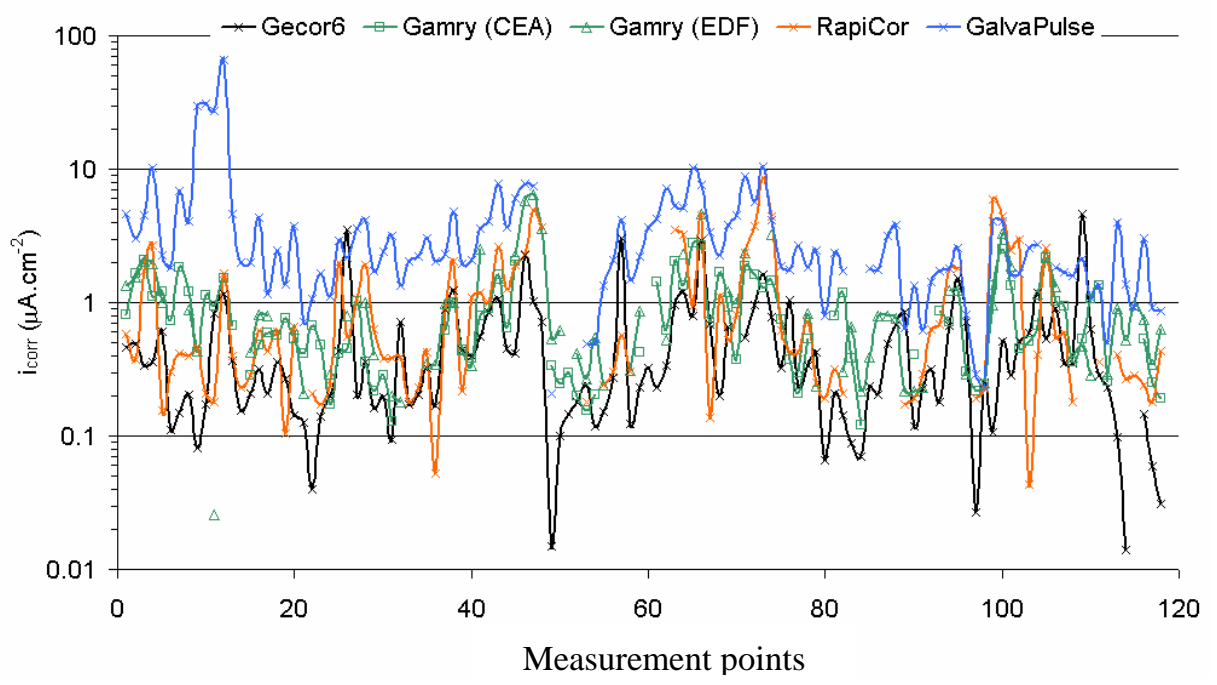

Figure 4: Corrosion rates measured with the four devices mentioned in the table 3. 
Moreover, for all devices, evolutions of the corrosion rate values are nearly similar. The peaks (meaning low or high values) observed from the Gecor6® device seem to be well correlated with data issued from the GalvaPulse ${ }^{\circledR}$ device.

\subsection{Corrosion rates measurements - effect of the constitutive material.}

First, a synthesis of corrosion rates measurements (from Gecor6® device) is presented and allows pointing out some general information. Then, the effect of different parameters (prestressing effect, concrete design) on instantaneous corrosion rates can be studied. Figure 5 presents a review of corrosion potential values and corrosion rates values (in $\mu \mathrm{A} \cdot \mathrm{cm}^{-2}$ ) measured on all beams. On the same graph, the corrosion defined for corrosion levels [11] are shown. The following observations may be made from the above graph:

- No direct relation is pointed out between the half-cell potential and the instantaneous corrosion rates $\left(\mathrm{I}_{\text {corr }}\right)$,

- $\quad$ Rebars from type 1 and 2 beams (centered prestressing) present corrosion rate values from low to moderate.

- Corrosion rate values measured on the lower face of type 4 and 6 beams (prestressed in their lower part) show a negligible or low corrosion activity.

- On the contrary, the upper faces of these beams present more important corrosion rate values, and the corrosion activity is moderate to high for type 6 beams.

- An important scatter is observed for dispersion corrosion rate values in type 9 beams.

After this global synthesis, remarks can be made on several parameters influencing corrosion rates. Figure 6 presents the corrosion rate values measured for the beams type 4 and 6 (prestressed on the lower part of the beam, and concrete cover of $16 \mathrm{~mm}$ on the 4 faces). Figure $6 \mathrm{a}$ shows the results for the concrete beams containing $300 \mathrm{~kg}$ cement per $\mathrm{m}^{3}$ of concrete, whereas the figure $6 \mathrm{~b}$ presents results obtained for the concrete containing $400 \mathrm{~kg}$ cement per $\mathrm{m}^{3}$ of concrete. 


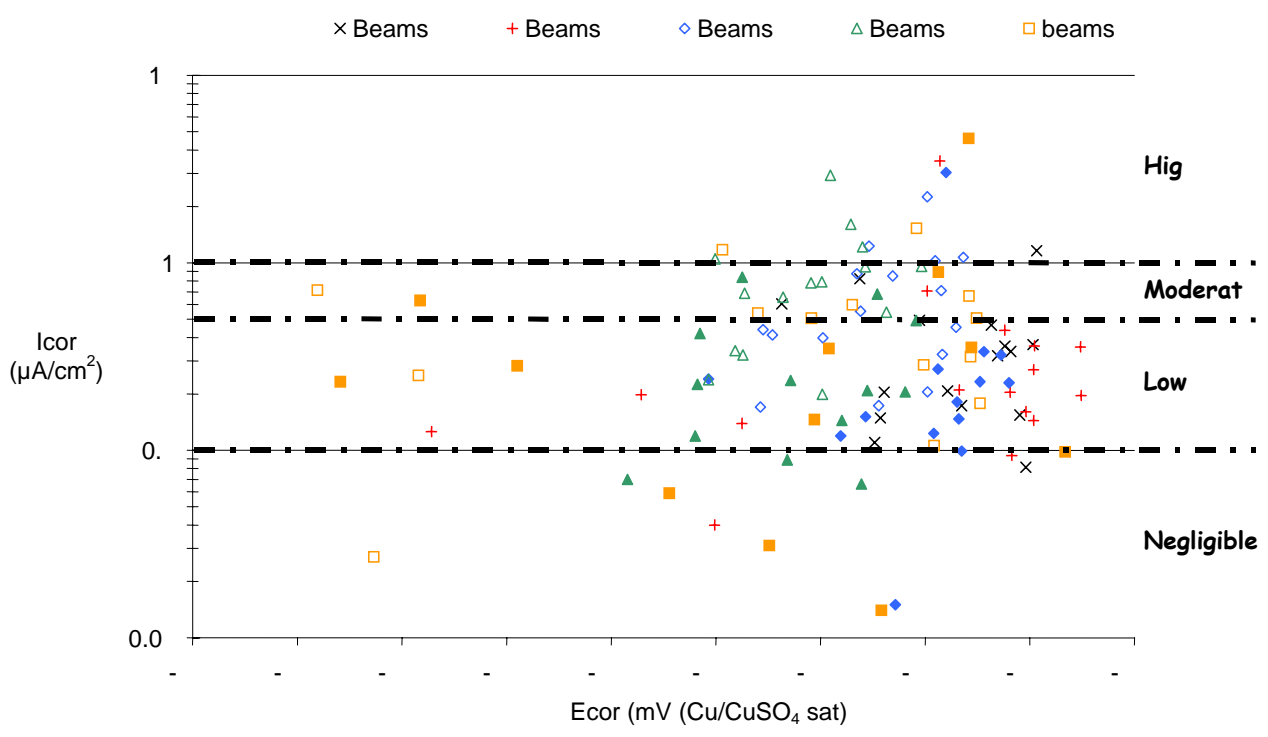

Figure 5: Corrosion rates measured on different locations on 20 beams. (for beams type 4, 6 and 9, $\boldsymbol{\nabla}$ = measurements on the lower face, $\square=$ measurements on the upper face).

For the two cases, graphs point out an important scatter of corrosion activity in the considered concrete zone. The measured corrosion rate is globally more important in the points located on the upper face (tensile area) than in points located on the lower part of the beam (lower face, compressive area). So, the corrosion rates are different in tensioned and in compressed faces of a beam, which is totally consistent with the visual observations presented previously. 
14 Revue. Volume $\mathrm{X}-\mathrm{n}^{\circ} \mathrm{x} /$ année
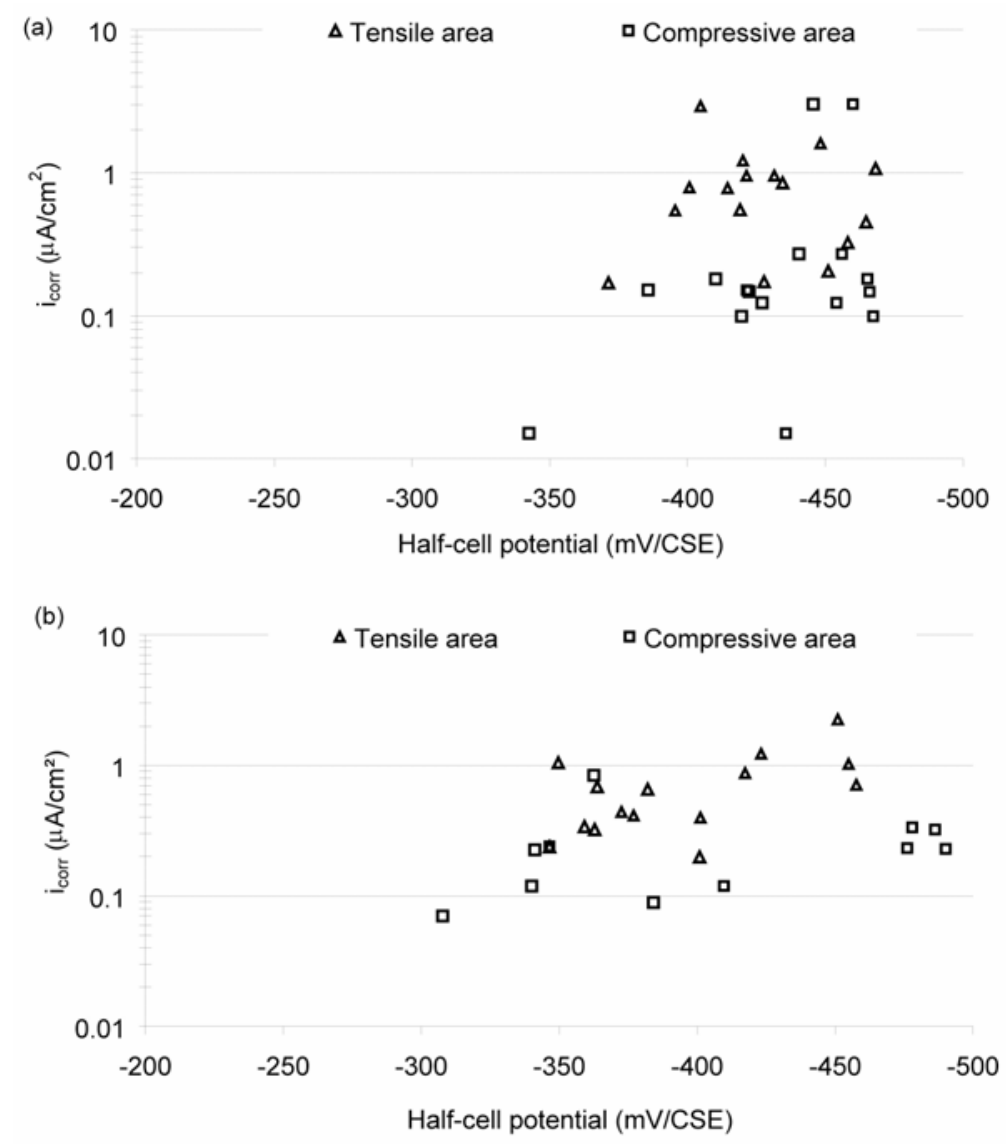

Figure 6: Influence of stress in concrete (tensile/compressive areas) on corrosion rate - cement contents (per $\mathrm{m}^{3}$ of concrete) (a) $300 \mathrm{~kg}$ (b) $400 \mathrm{~kg}$.

Figure 7 presents the influence of concrete design (cement content) on the corrosion activity. Figure 7(a) shows the corrosion rates and half-cell potential results of types 1 and 2 beams centrally prestressed, concrete cover $41 \mathrm{~mm}$ ), whereas Figure 7(b) presents these values for the types 4 and 6 beams (prestressed in the lower part, concrete cover $16 \mathrm{~mm}$ ). Moreover, for beams prestressed in their lower part, only measurements of the upper face are reported (tensile areas). 
(a)

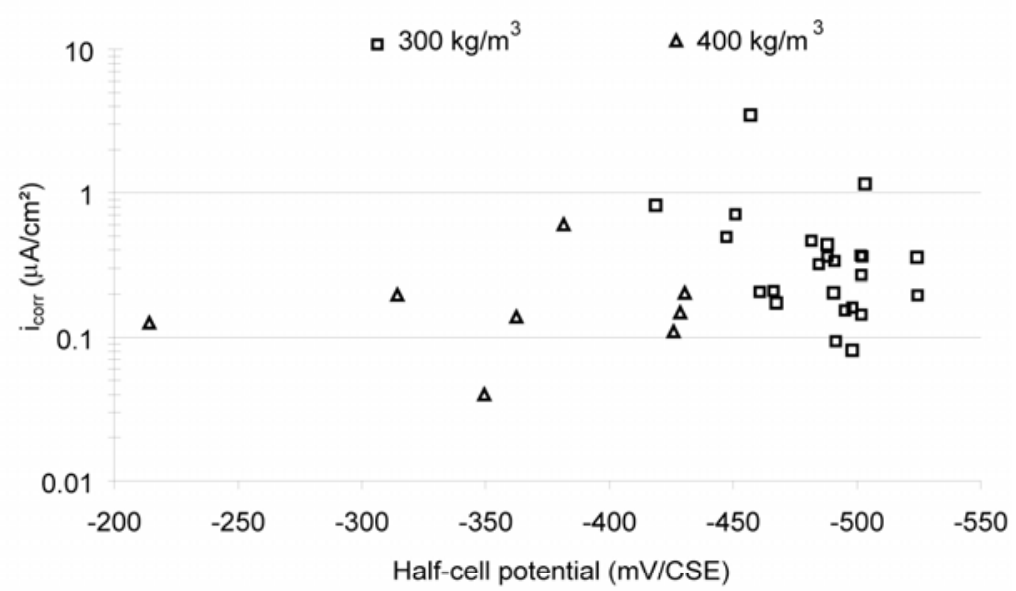

(b)

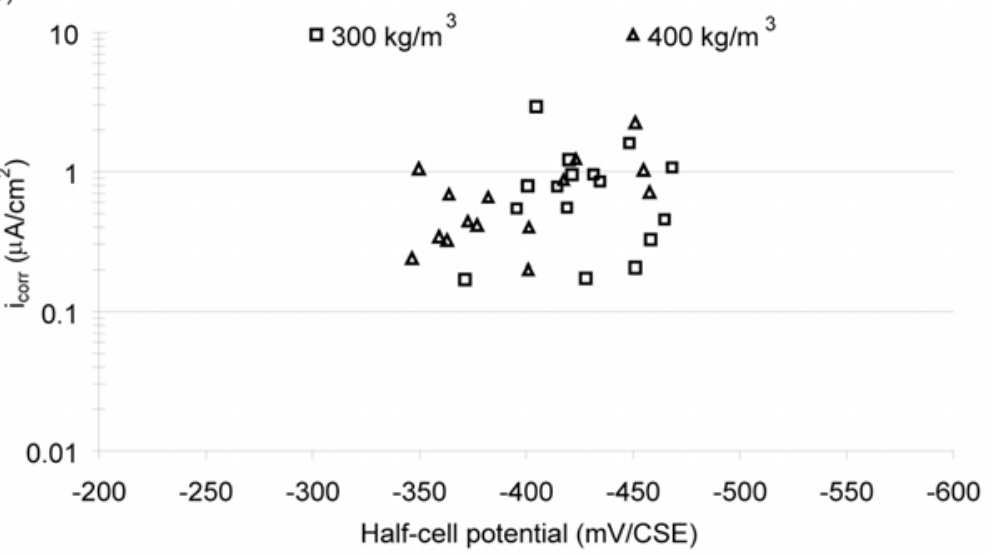

Figure 7: Influence of cement content on corrosion rates - concrete cover (a) $41 \mathrm{~mm}$ (b) $16 \mathrm{~mm}$.

The data of the beams type 1 and 2 (Figure 7a) clearly show that:

- Concrete with high content cement $\left(400 \mathrm{~kg} / \mathrm{m}^{3}\right)$ and a continue granulometry presents the lowest corrosion activities: these conclusions are drawn from corrosion rates values and from half-cell potentials measurements.

- Concretes with low content cement $\left(300 \mathrm{~kg} / \mathrm{m}^{3}\right)$ present highest corrosion rates and most negative half-cell potentials.

A similar analysis performed on type 4 and 6 beams (Figure 7b) does not point out any effect of the concrete design on corrosion activities. 


\section{ND analysis}

An analysis of results obtained from NDT measurements is presented. For each NDT tools a characteristic factor is defined and evaluated for each side of beams. The discussion is focused on comparing the various factors determined from nondestructive tools and the actual state of rebars. Only results obtained on upper and lower faces will be considered in this study. NDT factors (crack factor, direct wave amplitude, gradient potential factor, corrosion rate and resistivity) measured on upper and lower sides for each beam are presented in table 5.

Table 5: Numerical values of NDT factors ${ }^{1}$ and percentage of corroded areas for each beam

\begin{tabular}{|c|c|c|c|c|c|c|c|c|c|c|c|c|c|}
\hline & & \multicolumn{2}{|c|}{ Crack factor } & \multicolumn{2}{|c|}{$\begin{array}{r}\text { RADAR factor } \\
\text { (arbitrary unity) }\end{array}$} & \multicolumn{2}{|c|}{$\begin{array}{r}\begin{array}{r}\text { Potential gradient } \\
\text { factor } \\
\text { (in \%) }\end{array} \\
\end{array}$} & \multicolumn{2}{|c|}{$\begin{array}{c}\text { Corrosion rate } \\
\text { (in } \mu \text { m.year }{ }^{-1} \text { ) } \\
\end{array}$} & \multicolumn{2}{|c|}{$\begin{array}{r}\text { Resistivity } \\
\text { (in kOhm.cm) } \\
\end{array}$} & \multicolumn{2}{|c|}{$\begin{array}{r}\begin{array}{r}\text { Percentage of } \\
\text { corroded areas } \\
\text { (in \%) }\end{array} \\
\end{array}$} \\
\hline \multicolumn{2}{|c|}{$\begin{array}{c}\text { Designation } \\
\text { beam }\end{array}$} & $\begin{array}{l}\text { in upper } \\
\text { face }\end{array}$ & $\begin{array}{r}\text { in lower } \\
\text { face }\end{array}$ & $\begin{array}{l}\text { in upper } \\
\text { face }\end{array}$ & $\begin{array}{c}\text { in lower } \\
\text { face }\end{array}$ & $\begin{array}{c}\text { in upper } \\
\text { face }\end{array}$ & $\begin{array}{r}\text { in lower } \\
\text { face }\end{array}$ & $\begin{array}{r}\text { in upper } \\
\text { face }\end{array}$ & $\begin{array}{r}\text { in lower } \\
\text { face }\end{array}$ & $\begin{array}{c}\text { in upper } \\
\text { face }\end{array}$ & $\begin{array}{r}\text { in lower } \\
\text { face }\end{array}$ & $\begin{array}{r}\text { in upper } \\
\text { face }\end{array}$ & $\begin{array}{r}\text { in lower } \\
\text { face }\end{array}$ \\
\hline \multirow[t]{2}{*}{ Type 1} & 121 & 0 & 0 & 8742 & 9124 & 11.0 & 9.6 & 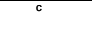 & 6.5 & . & 42.4 & 39.3 & 13.6 \\
\hline & 122 & 2.4 & 0 & 7181 & 8267 & 3.8 & 4.0 & c & 3.0 & c & 46.5 & 31.6 & 13.3 \\
\hline \multirow[t]{2}{*}{ Type 2} & 211 & 0 & 0 & 7708 & 7808 & 17.9 & 5.8 & c & 2.9 & $\mathrm{c}^{\mathrm{c}}$ & 66.1 & 30.3 & 28.9 \\
\hline & 212 & 0 & 0 & 10828 & 9894 & 9.5 & 17.4 & c & 1.5 & c & 89.4 & 8.1 & 5.5 \\
\hline \multirow[t]{4}{*}{ Type 4} & 411 & 9.3 & 0 & 8042 & 8185 & 15.9 & 5.0 & 2.5 & 1.3 & 52.9 & c & 28.3 & 22.1 \\
\hline & 412 & 21.4 & 0 & 8112 & 10129 & 30.3 & 3.3 & 8.5 & 2.1 & 30.9 & c & 36.9 & 2 \\
\hline & 421 & 0 & 1.6 & 8442 & 9240 & 20.9 & 8.8 & 8.5 & 2.1 & 13.3 & c & $\mathrm{a}$ & a \\
\hline & 422 & 13.5 & 12 & 7183 & 8167 & 35.3 & 4.5 & 12.8 & 3.2 & 25.6 & c & 16.6 & 12 \\
\hline \multirow[t]{4}{*}{ Type 6} & 611 & 10.1 & 0 & 8179 & 9164 & 44.1 & 5.5 & 17.1 & 2.4 & 22.1 & c & 84.4 & 6.3 \\
\hline & 612 & 31.2 & 0 & 9556 & 9855 & 15.6 & 14.8 & 6.0 & 0.9 & 36.6 & c & 39.9 & 2.1 \\
\hline & 621 & 7.9 & 0 & 7349 & 8810 & 24.6 & 11.1 & 11.3 & 4.7 & 20.9 & c & 55.2 & 9.2 \\
\hline & 622 & 52.9 & 0 & 8723 & 9329 & 20.5 & 5.8 & 5.6 & 4.6 & 43.4 & c & 50 & 14.6 \\
\hline \multirow[t]{4}{*}{ Type 9} & 911 & 21.9 & 16.3 & 8583 & 9268 & 8.7 & 9.3 & 7.8 & 6.2 & 42.1 & c & 24.2 & $\mathrm{~b}$ \\
\hline & 912 & 0 & 0 & 9589 & 9996 & 5.0 & 2.5 & 3.8 & 4.4 & 81.9 & c & 5.9 & b \\
\hline & 921 & 0 & 17.9 & 8601 & 9132 & 5.4 & 7.2 & 3.5 & 0.6 & 12.3 & c & 9.4 & b \\
\hline & 922 & 88.5 & 0 & 7948 & 8957 & 16.5 & 4.2 & 8.2 & 0.9 & 24.4 & c & 36.9 & b \\
\hline
\end{tabular}

The use of gradient potential (spatial variation) seems to be more pertinent to evaluate in a qualitative way the corrosion degree within reinforced concrete [10] [23] [24].

1 Crack factor $=\sum_{i=1}^{\mathrm{N}}$ length(i) $\times$ width(i) , where $\mathrm{N}$ is the number of cracks on the considered face.

Radar factor $=$ direct wave amplitude (Small DW amplitude (high moisture and/or chloride content) = High corrosion risk, High DW amplitude (low moisture and/or chloride content) = Low corrosion risk.) Potential gradient factor $=$ percentage of gradient potential values higher to $8 \mathrm{mV} . \mathrm{cm}^{-1}$, referred to [10] The higher this factor is, the higher corrosion risk exists.

Corrosion rate and resistivity measurements are evaluated from Gecor6 ${ }^{\circledR}$ unit using a guard ring counterelectrode that enables to confine polarisation in a known area. Corrosion rate is calculated by using a Tafel slope of $26 \mathrm{mV} /$ decade and is expressed in $\mu$ m.year ${ }^{-1}$ [11].

Percentage of corroded steel area is evaluated for upper and lower faces. 
Several observations can be formulated:

- for beams type 4, 6, and 9, radar factor values are systematically lower in upper sides, indicating a higher corrosion risk in this area.

- for these same beams, electrochemical factor values are higher in the upper sides, showing a high corrosion risk.

- except for beam 412, concrete mixture type 1.2 presents generally higher values (for radar factor and resistivity) and lower values (for electrochemical factors), indicating a better corrosion resistance of tfis concrete type.

The discussion concentrates on the comparison between the various factors determined from non-destructive tools and the actual state of rebars (defined as the percentage of corroded areas along beam). It can be noticed that similar conclusions could be formulated by considering mean corrosion attack penetration.

In order to evaluate the expected relations between the NDT factors and the percentage of corroded areas, the results expressed in these terms are plotted in figure 8. On these graphs are distinguished values estimated on lower and upper sides for each beam.

Except for the "crack" factor index, a good qualitative accordance is observed between corrosion damage from NDT factors and corroding rebar area. As expected, a correlation is observed between electrochemical parameters (gradient potential and corrosion rate). Concerning radar results, a tendency is found between the DW amplitude value and the corroded areas at rebar surface. That is in good agreement with previous laboratory results [15, 25]: DW amplitude decreases where corrosion risks are higher (and a higher percentage of corroded areas is noticed).

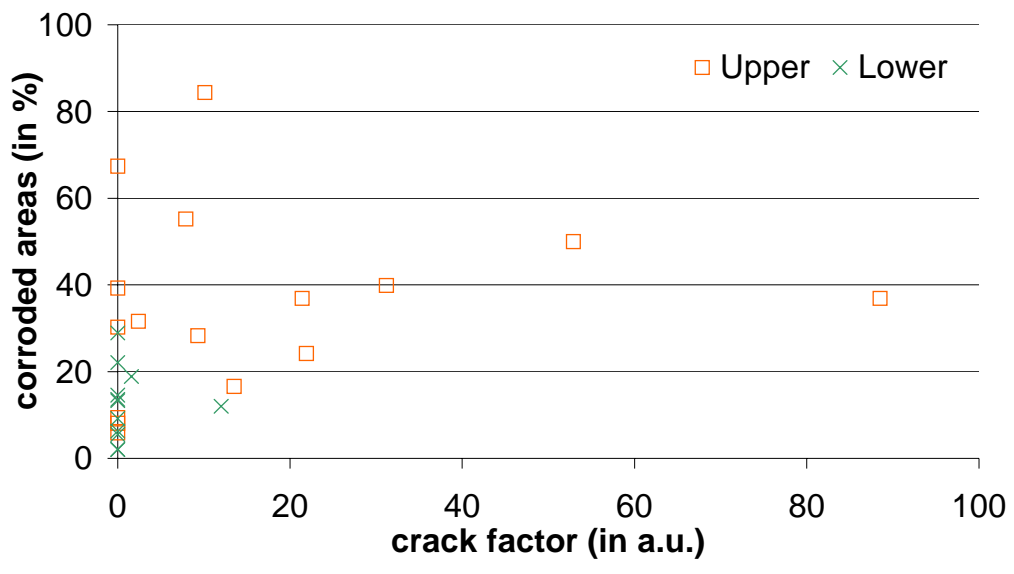


18 Revue. Volume $\mathrm{X}-\mathrm{n}^{\circ} \mathrm{x} /$ année
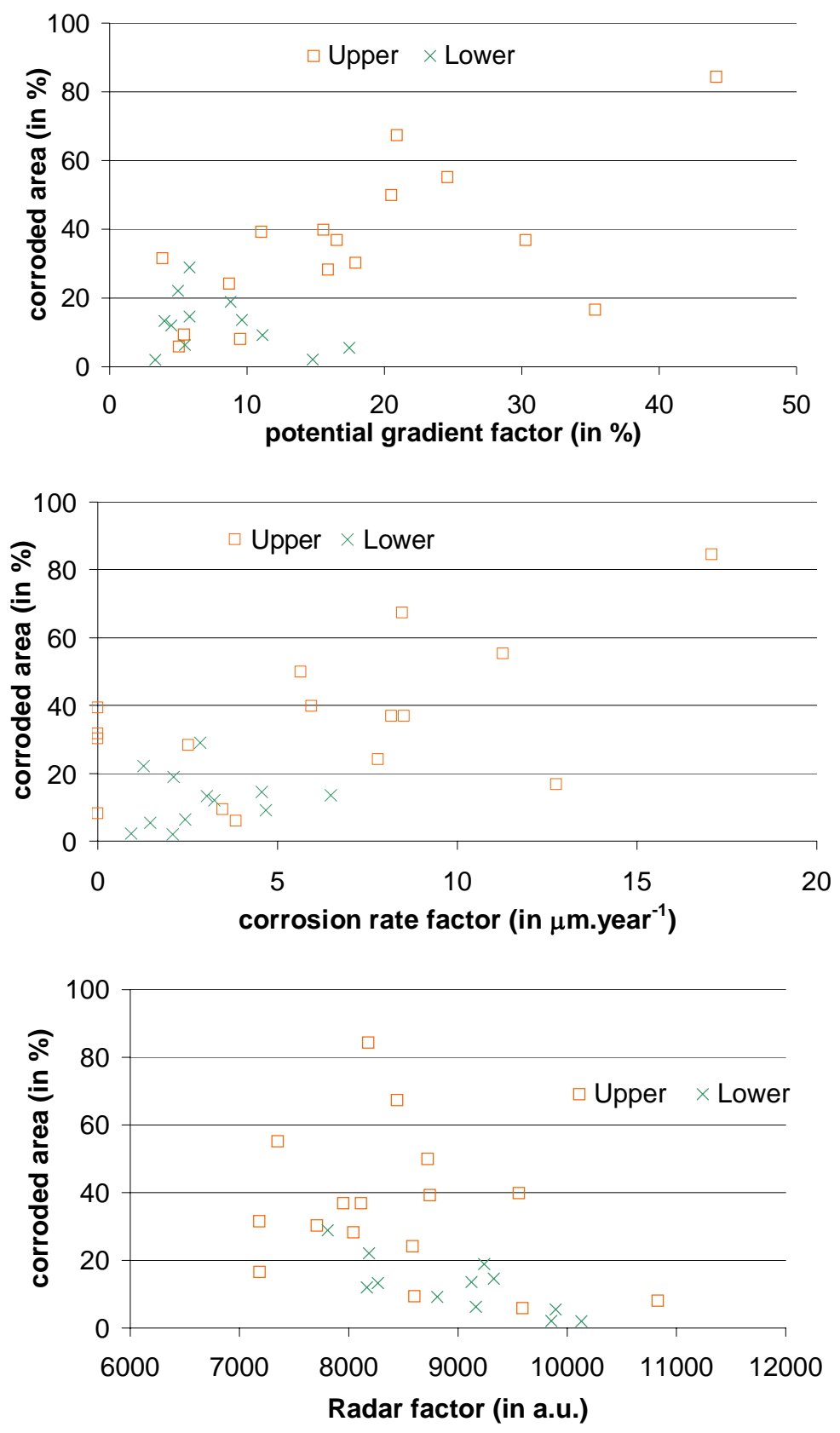

Figure 8: Comparison between corroded area of rebars and NDT factors 
It is interesting to notice that in the case of a non-expected result, NDT indicators confirm actual corrosion damage risk. For example, due to its concrete design (high cement content), beam 412 should show a good corrosion behaviour. However a high corrosion damage is visually observed in upper part of this beam compared to the others beams type 4 . NDT indicators values measured on the upper face of this beam are in good agreement with the real corrosion state (high potential gradient and corrosion rate values and low DW amplitude).

Finally, in the case of type 4, 6 and 9 beams, NDT factors confirm the difference of activity, for a same beam, between the upper and lower parts. As confirmed by visual observations after removing concrete, higher corrosion activities are observed for these beams on rebars located in the upper part.

\section{Conclusion}

This paper presents a corrosion diagnosis of 20 prestressed concrete beams after 40 years exposure in marine environment. It is performed from simple criteria for each Non Destructive Testing tools used in this project. Physico-chemical measurements have confirmed that chloride ions are the only responsible of corrosion attack. The corrosion damage diagnosis has allowed establishing the following conclusions:

- Crack maps gives a global overview of the corrosion area (but only when the corrosion process reaches a critical issue).

- The tensile/compressive stresses within concrete structure have a significant effect on corrosion of passive reinforcing steel. Conclusion on an "active" corrosion in the tensile part of the beam and a "low" corrosion in the compressive part can be made with confidence.

- The thickness of concrete cover and w/c are important factors determining the ability of aggressive species (chloride and oxygen in our study case) to access to the rebar surface and to develop corrosion process.

- The NDT indicators proposed in this study are sensitive with the corrosion risk of rebars within concrete structures and will have to be of a first relevance to establish a diagnostic of corrosion activity.

These first results are encouraging tendencies to place confidence in such NDT tools (radar, half-cell potential (using spatial gradient values) and corrosion rate values deduced from polarization resistance measurements) to control and evaluate in a qualitative way (for electrochemical indicators at least) the corrosion risk within real reinforced concrete structure. These results will be used for modelling the influence of corrosion damage on mechanical behaviour of such reinforced concrete beams after a long-term exposure in natural marine environment. 


\section{References}

1. K. Tuutti, "Corrosion of steel in concrete", in: CBI Research Report $n^{\circ} 4.82$, Swedish Cement and Concrete Research Institute, Stockholm, Sweden (1982).

2. Neville A., "Chloride attack of reinforced concrete: an overview"; ACI Materials and Structures, vol.28, 1995, pp. 63-70.

3 Montemor M.F. et al, "Chloride-induced corrosion on reinforcing steel: from the fundamentals to the monitoring techniques"; Cement and Concrete Composites, vol.25, 2003, pp. 491-502.

4. Huet B. et al, "Electrochemical behavior of mild steel in concrete: Influence of $\mathrm{pH}$ and carbonate content of concrete pore solution”; Electrochimica Acta, vol.51 n²1, 2005, pp. 172-180.

5 Ahmad S., "Reinforcement corrosion in concrete structures, its monitoring and service life prediction - a review”; Cement and Concrete Composites, vol.25, 2003, pp. 459-471.

6. Castel A. et al, "Mechanical behavior of corroded reinforced concrete beams: Part 1. Experimental study of corroded beams"; Materials and Structures, vol.33, 2000, pp. 539544.

7. Rodriguez J. et al, "Load carrying capacity of concrete structures with corroded reinforcement”; Construction Building Materials, vol.11, 1997, pp. 239-248.

8. Dekoster M. et al, "Modelling of the flexural behaviour of RC beams subjected to localised and uniform corrosion”; Engineering Structures, vol.25, n¹0, 2003, pp. 13331341.

9 Vié D. et al., "Benchmark des poutres de la Rance - comportement mécanique de poutres corrodées - Partie expérimentale”, Revue européenne de génie civil, this volume.

10. RILEM TC 154-EMC, "Half-cell potential measurements. Potential mapping on reinforced concrete structures”; Materials and Structures, vol.36, 2003, pp. 461-471.

11. RILEM TC 154-EMC, "Test methods for on-site corrosion rate measurement of steel reinforcement in concrete by means of the polarization resistance method"; Materials and Structures, vol.37, 2004, pp. 623-643.

12. Stern M., Geary A.L., "Electrochemical polarization I: theoretical analysis of shape of polarization curves”; Journal of Electrochemistry Society, vol.104, 1957, pp. 56-63.

13. Clemena G.G., "Short-pulse radar methods", in: Malhotra, Carino, eds. CRC Handbook of non destructive testing of concrete: CRC Press, 1991.

14. Daniels D.J., “Surface-penetrating radar”, in: London, UK: Institute of Electrical Engineers, 1996.

15. Laurens S. Aptitude de la technique radar à la caractérisation du béton d'enrobage-Aide au diagnostic de la corrosion des armatures, Doctoral Thesis. INSA Toulouse (FR), Sherbrooke University (CA); 2001.

16. Castellote M. and Andrade C., "Round-Robin test on chloride analysis in concrete - Part 1 and Part 2 -”; Materials and Structures, vol.34, 2001, pp. 532-556. 
17. R. François and G. Arliguie, Magazine of Concrete Research, 51 (1999) 143-150.

18. C. Alonso, C. Andrade, M. Castellote, P. Castro, Cement and Concrete Research, 30 (2000) 1047-1055.

19. M. Raupach, Construction and Building Materials, 10 (1996) 329-338.

20 O. Poupard, V. L’Hostis, S. Catinaud, I. Petre-Lazar, Corrosion damage diagnosis of a reinforced concrete beam after 40 years natural exposure in marine environment, Cement and Concrete Research, Vol. 36, pp. 504-520 (2006).

21. Klinghofer O., "Assessment of Reinforcement Corrosion by Galvanostatic Pulse Technique", Proceedings International Conference on Repair of Concrete Structures, Norway, pp. 391-400, 1997.

22. Tang Luping, "Calibration of the Electrochemical Methods for the Corrosion Rate: Measurement of Steel in Concrete", NORDTEST Project No. 1531-01, SP Report 2002:25, 58 pages, 2002.

23. G. Grimaldi, P. Brevet, G. Pannier, A. Raharinaivo, "Factors influencing electrode potential of steel in concrete”, British Corrosion, 21 (1986) 55-62.

24. I. Medgyesi, J. Berecz, A. Jantai, M. Kelemen, "Contrôle de la corrosion des armatures dans les structures en béton armé”, Bulletin des Liaisons du LCPC, 158 (1988) 29-38.

25. G. Klysz, «Caractérisation du béton d'enrobage par technique Radar : exploitation de l'onde directe emetteur-récepteur », Doctoral thesis, Université Paul Sabatier (LMDC), Toulouse, 2004. 